\title{
DAMPAK BURUK RADIASI PONSEL BAGI KESEHATAN
}

\author{
Sergiana F.Saba Jawa , Muhammad Ali Sodik \\ INSTITUT ILMU KESEHATAN STRADA INDONESIA \\ sergianafitnisari@gmail.com, Alisodik2012@gmail.com
}

\begin{abstract}
ABSTRAK
Telepon genggam atau telepon seluler (disingkat ponsel) atau handphone (disingkat HP) adalah perangkat telekomunikasi elektronik yang mempunyai kemampuan dasar yang sama dengan Juhdan konvensional saluran tetap, tetapi dapat dibawa ke mana-mana.

Ponsel atau HP memancarkan radiasi Radio Frequency (RF) tingkat rendah. Radiasi yang dipancarkan HP merupakan suatu bentuk radiasi elektromagnetik yang dapat diserap oleh jaringan tubuh saat berdekatan dengan alat tersebutJumlah radiasi RF yang dapat dipaparkan kepada pengguna HP tergantung pada banyak faktor. Mulai dari teknologi dari HP yang digunakan, jarak antara HP dan pengguna, tingkat serta jenis penggunaan HP.

Radiasi mungkin sudah akrab di telinga kita, namun jarang kita ketahui secara benar apa itu radiasi. Radiasi adalah energi yang bergerak dalam bentuk gelombang atau partikel kecil dengan kecepatan tinggi. Secara alami, radiasi ada pada sinar matahari. Sedangkan, radiasi yang dibuat manusia berada dalam bentuk sinar$\mathrm{x}$, senjata nuklir, pembangkit listrik tenaga nuklir, dan pengobatan kanker.

Paparan radiasi hp dapat mengganggu tingkat emosinya, Malas belajar dan terjadi perubahan prilaku misalnya menjadi mudah tersinggung dan rewel. Menggunakan hp terlalu panas menyebabkan efek panas pada telinga dan menganggu saraf saeraf pendengaran bagian dalam.
\end{abstract}

Kata Kunci : Ponsel/HP, Radiasi .

\section{Latar Belakang}

Telepon genggam atau telepon seluler (disingkat ponsel) atau handphone (disingkat HP) adalah perangkat telekomunikasi elektronik yang mempunyai kemampuan dasar yang sama dengan Juhdan konvensional saluran tetap, tetapi dapat dibawa ke mana-mana.

Ponsel atau HP memancarkan radiasi Radio Frequency (RF) tingkat rendah. Radiasi yang dipancarkan HP merupakan suatu bentuk radiasi elektromagnetik yang dapat diserap oleh jaringan tubuh saat berdekatan dengan alat tersebut.

Satu-satunya efek biologis dari radiasi RF dari pada manusia adalah rasa panas, yang termasuk efek dari radiasi HP. Layaknya microwave yang digunakan untuk memanaskan makanan, paparan RF dari penggunaan HP dapat menyebabkan kamu merasa kepanasan. Tepatnya beberapa area tubuh yang dekat atau menempel dengan HP saat digunakan.Seperti kepala, telinga tau tangan. Namun, seberapa tinggi kenaikan suhu tubuh akibat penggunaan HP pun belum dapat diteliti secara jelas. Memang berbagai efek kesehatan akibat penggunaan HP banyak dilaporkan.Salah satu yang menjadi perhatian adalah efek neurologis atau gangguan saraf pada anak muda, karena otak adalah organ utama yang terpapar. Namun, penelitian mengenai hal tersebut belum menghasilkan temuan yang konsisten. Sehingga belum bisa dipastikan.Risiko kesehatan paling konsisten yang terkait dengan penggunaan HP yang paling jelas adalah gangguan mengemudi serta kecelakaan lalu lintas. Penelitian telah menunjukkan peningkatan risiko kecelakaan lalu lintas akibat penggunaan HP. Dan Menurut penelitain, HP atau ponsel jenis apapun 
memiliki radiasi elektromagnetik yang dapat mengurangi kualitas tidur. Hal ini mengakibatkan aliran darah ke otot-otot Anda tidak akan berjalan maksimal. Kondisi tersebut membuat tubuh akan kesulitan berkonsentrasi, nyeri, dan kurang fokus saat bangun di pagi hari.

\section{Rumusan Masalah}

a.Apa efek samping radiasi hp ?

b. Bagaimana cara mengurangi radiasi HP ?

C.Apa bahaya tidur dekat Hp ?

*. Radiasi hp dapat merusak saraf saraf kepala dan mengacaukan sistem motorik sehingga menyebabkan otot seputar otak menjadi tertekan dan kelelahan lalu memicu munculnya penyakit parkinson.

*.Untuk mengatasi bahaya radiasi handphone dibawah ini beberapa tips yang perlu diketahui :

1.Mengaktifkan speaker.

2. Lebih baik SMS.

3. Setting ke mode off line.

4.Memakai hand phone sebaiknya di ruang yang luas.

5.Lihat indikator penerimaan sinyal.

6. Memakai telinga secara bergantian.

7. Menelepon seperlunya saja.

*.Menurut penelitain, HP atau ponsel jenis apapun memiliki radiasi elektromagnetik yang dapat mengurangi kualitas tidur. Hal ini mengakibatkan aliran darah ke otot-otot Anda tidak akan berjalan maksimal. Kondisi tersebut membuat tubuh akan kesulitan berkonsentrasi, nyeri, dan kurang fokus saat bangun di pagi hari.

\section{Tinjauan Pustaka}

\section{a.Ponsel / Handphone}

Telepon genggam atau telepon seluler (disingkat ponsel) atau handphone (disingkat HP) adalah perangkat telekomunikasi elektronik yang mempunyai kemampuan dasar yang sama dengan Juhdan konvensional saluran tetap, tetapi dapat dibawa ke mana-mana

(bahasa Inggris: portable atau mobile) dan tidak perlu disambungkan dengan jaringan telepon menggunakan kabel (komunikasi nirkabel, bahasa Inggris: wireless communication). Saat ini, Indonesia mempunyai dua jaringan telepon nirkabel yaitu sistem GSM (Global System Mobile Telecommunications) dan sistem CDMA (Code Division Multiple Access). Badan yang mengatur telekomunikasi 1-G merupakan telepon genggam pertama yang sebenarnya. Tahun 1973, Martin Cooper dari Motorola Corp menemukan telepon genggam pertama dan diperkenalkan kepada publik pada 3 April 1973. Telepon genggam yang ditemukan oleh Cooper memiliki berat 30 ons atau sekitar 800 .

\section{b.Radiasi Handphone}

Ponsel atau HP memancarkan radiasi Radio Frequency (RF) tingkat rendah. Radiasi yang dipancarkan HP merupakan suatu bentuk radiasi elektromagnetik yang dapat diserap oleh jaringan tubuh saat berdekatan dengan alat tersebut. 


\section{Pembahasan}

handphone (disingkat HP) adalah perangkat telekomunikasi elektronik yang mempunyai kemampuan dasar yang sama dengan Juhdan konvensional saluran tetap, tetapi dapat dibawa ke mana-mana,

Ponsel atau HP memancarkan radiasi Radio Frequency (RF) tingkat rendah. Radiasi yang dipancarkan HP merupakan suatu bentuk radiasi elektromagnetik yang dapat diserap oleh jaringan tubuh saat berdekatan dengan alat tersebut. Satu-satunya efek biologis dari radiasi RF dari pada manusia adalah rasa panas, yang termasuk efek dari radiasi HP. Layaknya microwave yang digunakan untuk memanaskan makanan, paparan RF dari penggunaan HP dapat menyebabkan kamu merasa kepanasan.

Radiasi hp juga dapat merusak saraf saraf kepala dan mengacaukan sistem motorik sehingga menyebabkan otot seputar otak menjadi tertekan dan kelelahan lalu memicu munculnya penyakit parkinson.

Untuk mengatasi bahaya radiasi handphone dibawah ini beberapa tips yang perlu diketahui :

1.Mengaktifkan speaker.

2. Lebih baik SMS.

3. Setting ke mode off line.

4.Memakai hand phone sebaiknya di ruang yang luas.

5.Lihat indikator penerimaan sinyal.

6. Memakai telinga secara bergantian.

7. Menelepon seperlunya saja.

Menurut penelitain, HP atau ponsel jenis apapun memiliki radiasi elektromagnetik yang dapat mengurangi kualitas tidur. Hal ini mengakibatkan aliran darah ke otot-otot Anda tidak akan berjalan maksimal. Kondisi tersebut membuat tubuh akan kesulitan berkonsentrasi, nyeri, dan kurang fokus saat bangun di pagi hari.

\section{Kesimpulan}

Telepon genggam atau telepon seluler (disingkat ponsel) atau handphone (disingkat HP) adalah perangkat telekomunikasi elektronik yang mempunyai kemampuan dasar yang sama dengan Juhdan konvensional saluran tetap, tetapi dapat dibawa ke mana-mana.

Bahaya Radiasi Hp :

Menurut penelitain, HP atau ponsel jenis apapun memiliki radiasi elektromagnetik yang dapat mengurangi kualitas tidur. Hal ini mengakibatkan aliran darah ke otot-otot Anda tidak akan berjalan maksimal. Kondisi tersebut membuat tubuh akan kesulitan berkonsentrasi, nyeri, dan kurang fokus saat bangun di pagi hari. Untuk mengatasi bahaya radiasi handphone dibawah ini beberapa tips yang perlu diketahui :

1.Mengaktifkan speaker.

2. Lebih baik SMS.

3. Setting ke mode off line.

4.Memakai hand phone sebaiknya di ruang yang luas.

5.Lihat indikator penerimaan sinyal.

6. Memakai telinga secara bergantian.

7. Menelepon seperlunya saja.

\section{Daftar Pustaka}


Sodik, M. A., Suprapto, S. I., \& Pangesti, D. (2013). Faktor-Faktor Yang Berhubungan Dengan Pelaksanaan Pelayanan Prima Pegawai Di Rsui Orpeha Tulungagung. STRADA Jurnal Ilmiah Kesehatan, 2(1), 24-32. Deriyanthi,Fitrianti, ( 2020, June 24) " Ini Fakta Yang Sebenarnya di Balik Dugaan Bahaya Radiasi Hp Bagi Kesehatan"

https://www.gooddoctor.co.id/hidup-sehat/info-sehat/ini-fakta-yang-sebenarnya-di-balik-dugaan-bahayaradiasi-hp-bagi-kesehatan/.

https://id.wikipedia.org/wiki/Telepon_genggam. 